\title{
Mechanical properties of adobe bricks in ancient constructions
}

\author{
Dora Silveira, Humberto Varum , Aníbal Costa, Tiago Martins, Henrique Pereira, João Almeida
}

Keywords:

Adobe brick

Mechanical properties

Experimental testing

Earth architecture and construction

Traditional construction

Rehabilitation

Aveiro

\begin{abstract}
A B S T R A C T
A study of the mechanical properties of adobe bricks collected from houses and land dividing walls in Aveiro district, Portugal, representative of existing traditional constructions, was conducted. Cylindrical adobe specimens were subjected to simple compression and splitting tests. From these tests it was possible to evaluate the strength capacity, stiffness and deformation evolution for increasing loading. Correlations between the evaluated properties were determined, and the results obtained for houses and land dividing walls were compared. This study contributes for the characterization of adobes traditionally used in Aveiro district, and provides reference values that can be considered in rehabilitation processes
\end{abstract}

\section{Introduction}

Earth is one of the oldest and most widespread construction materials. It is estimated that approximately $30 \%$ of world population lives in earth buildings, and that about $50 \%$ of developing countries population, including the majority of rural population and at least $20 \%$ of urban and marginal urban population, lives in earth buildings [1].

In the past, earth was also a very common construction material in Portugal. Adobe, in particular, was used throughout many years in almost all types of construction, in littoral center, particularly in Aveiro district $[2,3]$. Construction with adobe declined in the middle of the 20th century, with the development of cement industry [4]. Presently, according to information from Aveiro municipality, about 25\% of the existing buildings in Aveiro city are made of adobe and, for the entire district, this percentage rises to $40 \%$. The important expression of this building system in some areas of Aveiro district has been confirmed by surveys carried out recently $[5,6]$. Adobe can be found in several types of construction: rural and urban buildings, many of which are still in use, walls for the delimitation of properties, water wells, churches and warehouses (Fig. 1). Many of the urban adobe buildings present cultural, historical and architectonic recognized value, as for example the buildings of the "Art Nouveau" style.
The success of adobe construction in Aveiro district was principally a result of the characteristics of the existing available raw materials. The main applied raw materials were coarse sand, argillaceous earth and lime. The natural earth mixtures were corrected by the addition of clay or sand and it was also common the addition of fibers (straw or sisal, for example) to control cracking while adobes were drying in the sun.

Adobe is a construction material that presents several attractive characteristics. It is low cost, locally available, recyclable, adapted to a large variety of soils, presents good thermal and acoustic properties, and is associated to simple constructive methods that require reduced energy consumption [7]. Adobe construction, however, if not properly designed and strengthened, may present a deficient response when subjected to seismic actions, suffering severe structural damage and often reaching collapse, as observed in recent earthquakes $[8,9]$.

The techniques adopted in the construction of adobe buildings in Aveiro district were based in the accumulated empirical knowledge, without a special concern with seismic safety. In addition, rehabilitation and strengthening of existing adobe constructions have been neglected during the last decades. As a result, this constructed park is not adequately reinforced to withstand seismic actions, suffering various structural anomalies and deficiencies. Structural rehabilitation of the existing adobe constructions is therefore demanded. It will contribute for an improvement in the quality of life of those who use these constructions and for an increase of associated safety levels, particularly if effective seismic strengthening is provided. It presents, however, important difficulties, especially due to the lack of existing knowledge concerning 

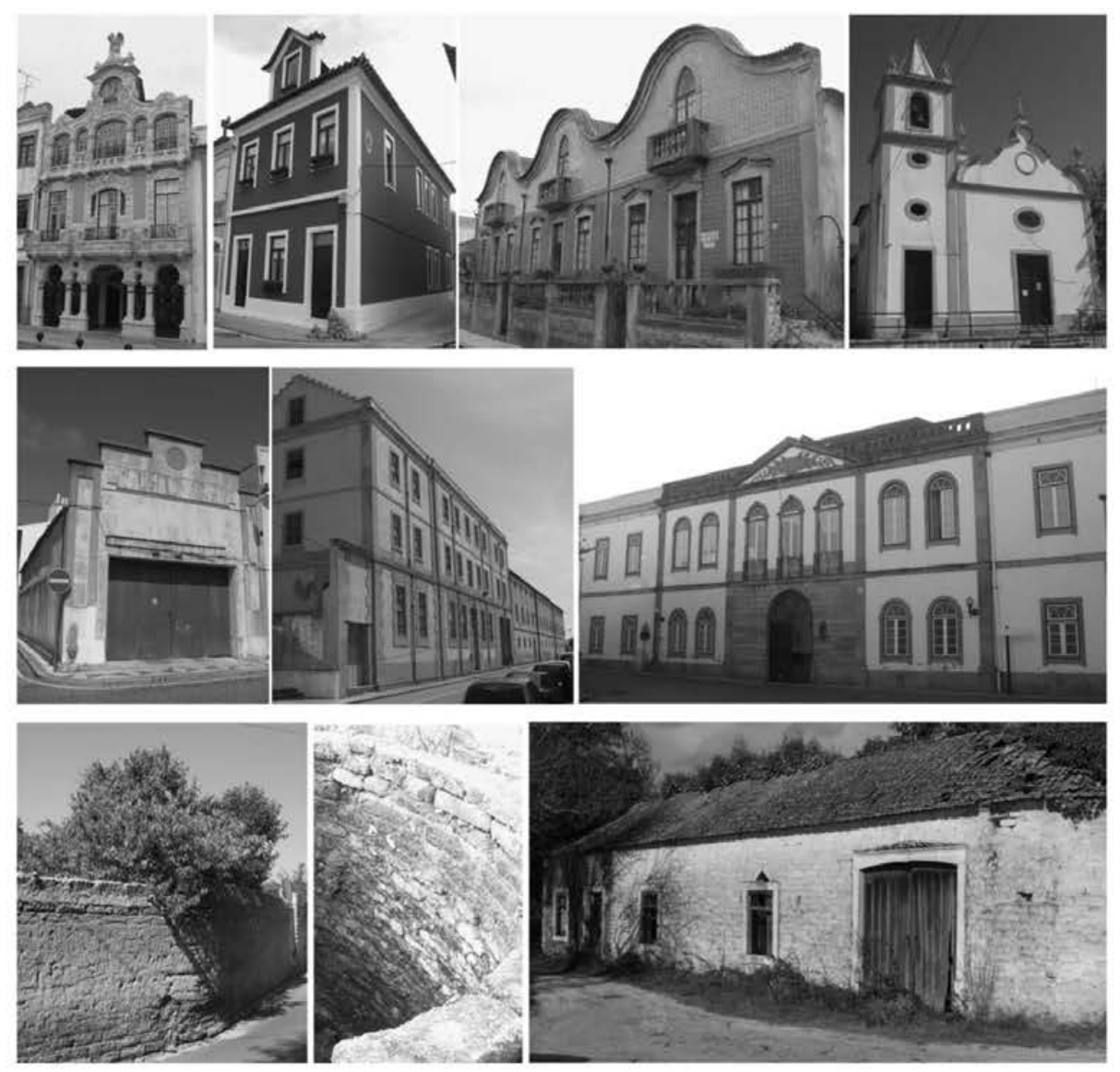

Fig. 1. Examples of existing adobe constructions in Aveiro district.

properties and characteristics of the mechanical behavior of adobe masonry. Technical studies of these properties and characteristics are necessary, and will constitute an essential instrument in the support of rehabilitation and strengthening projects, and also in the support of the design of new adobe constructions [10]. To contribute to this objective, a research group of the Civil Engineering Department, from University of Aveiro, has been developing studies and experimental tests [5,6,11-13]. The work in development intends to characterize the constructive and structural systems and common pathologies of the existing adobe constructions in Aveiro district, and to develop repair and strengthening solutions for these constructions.

In the investigation of the structural behavior of adobe buildings, the study of the mechanical behavior of the constituent materials of adobe masonry is an important first step [14]. A study of adobe specimens taken from houses and land dividing walls, representative of the existing construction in Aveiro district, has been conducted and is presented in this paper. Cylindrical adobe specimens were subjected to simple compression and splitting tests. These tests allow the evaluation of the strength capacity of the material, and the stiffness and deformation evolution for increasing loading. The results presented are important for the characterization of the adobes traditionally used in Aveiro district, and constitute reference values that can be considered in interventions on existing adobe constructions.

\section{Standards and technical recommendations}

It was conducted a research of the existing standards and technical recommendations for adobe construction. The following documents, which were considered the most complete, were carefully analyzed: 'Norma técnica de edificación NTE E.080 Adobe' [15]; 'NZS 4297:1998 Engineering design of earth buildings' [16]; 'NZS 4298:1998 Materials and workmanship for earth buildings' [17]; 'NZS 4299:1998 Earth buildings not requiring specific design' [18]; '2009 New Mexico earthen building materials code' [19]; 'The Australian earth building handbook' [20].

The consulted documents concern the testing of materials for new constructions, and the materials that are analyzed within this study were collected from old constructions, many of which are significantly degraded. Considering this and the limitations of the available laboratory facilities, it was verified that in the conduction of tests it would not be possible to rigorously comply with normative recommendations. The indications of the Australian handbook [20], which are the most adequate to the available laboratory facilities, were considered, but were regarded as guiding references, and not as strict rules.

The consulted documents indicate flexural tests for the determination of the tensile strength. It was decided to conduct splitting tests, instead, as these are more adequate to the existing laboratory facilities. In addition, splitting tests present some advantages - a splitting test more closely resembles a direct tension test, and the obtained results are less variable than in a flexural test (according to studies on the testing of concrete specimens) [21]. The RILEM technical recommendation 'CPC 6 Tension by splitting of concrete specimens' [22], which is addressed to concrete, was used as a guiding reference in the conduction of the splitting tests.

\section{Selection, preparation and testing of specimens}

For the experimental testing campaign, a set of samples representative of different existing adobe construction typologies was 

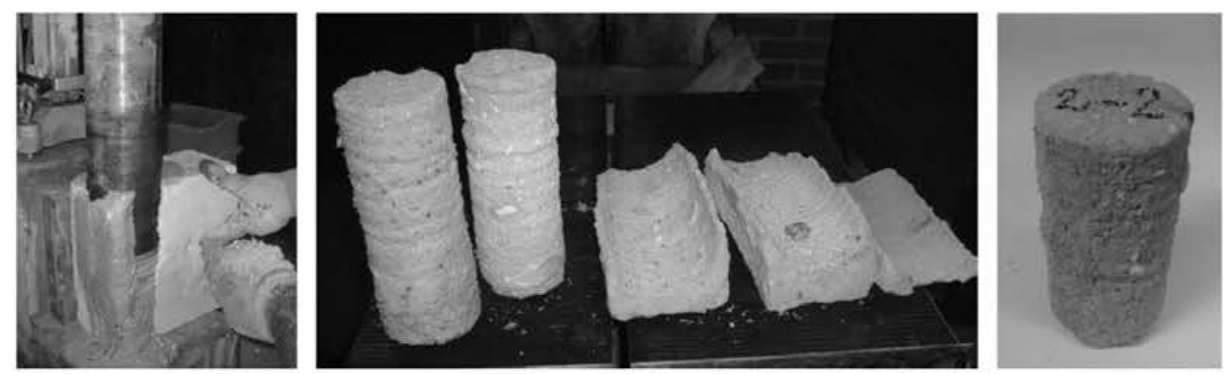

Fig. 2. Cylindrical cores extracted from the collected adobe bricks.
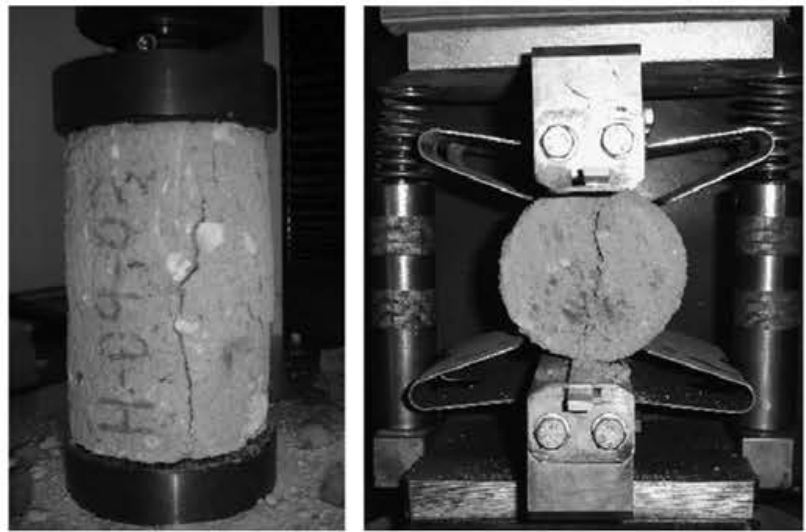

Fig. 3. Simple compression test and splitting test on adobe specimens.

selected from eight houses and eight land dividing walls, from different locations in Aveiro district. Samples were constituted, whenever possible, by entire adobe blocks. The mean dimensions of the collected adobe blocks are $0.45 \times 0.30 \times 0.12 \mathrm{~m}^{3}$, for houses, and $0.45 \times 0.20 \times 0.12 \mathrm{~m}^{3}$, for land dividing walls.

The standards and technical recommendations for earth construction consulted in this study [15-20] indicate that simple compression tests shall be conducted on adobe blocks or cubic specimens. These documents refer to new constructions, and thus to specimens that can be specifically molded for testing. The Australian handbook [20] admits the possibility of testing cylindrical specimens.
In this study, tests were conducted on cylindrical specimens with a height to diameter ratio of approximately 2 , for the following reasons:

(a) Considering the limitations of the available laboratory facilities, the extraction of cylindrical specimens from existing adobe bricks is simpler than the extraction of cubic specimens as it only implies cutting and regularizing three surfaces; it is important to note, however, that the extraction of cylindrical specimens is only viable for adobe units that do not possess large particles in their constitution, as was the case of the majority of the adobes collected, because these particles can damage specimens during the extraction process.

(b) When simple compression tests are conducted on cylinders with a height/diameter ratio of 2 , the failure stress is closer to the unconfined compressive strength, when compared to the obtained in the testing of cubes, because the effects of end restraint are reduced (according to studies on the testing of concrete specimens) [23].

(c) According to the RILEM technical recommendation 'CPC 6 Tension by splitting of concrete specimens' [22], splitting tests shall be conducted on cylindrical specimens with a height to diameter ratio of 2 , and thus the process of preparation of specimens for both tests was simplified.

Cylindrical specimens were extracted from the collected adobe bricks with diameters ranging from 80 to $90 \mathrm{~mm}$ (Fig. 2). A few specimens were extracted with smaller diameters due to defects in the adobe bricks.

Table 1

Results obtained in the mechanical tests conducted on adobe specimens.

\begin{tabular}{|c|c|c|c|c|}
\hline Construction & $\begin{array}{l}\text { Mean compressive } \\
\text { strength }(\mathrm{MPa})\end{array}$ & $\begin{array}{l}\text { Mean modulus of } \\
\text { elasticity }(\mathrm{MPa})\end{array}$ & $\begin{array}{l}\text { Mean strain at } \\
\text { peak strength }(\%)\end{array}$ & $\begin{array}{l}\text { Mean tensile } \\
\text { strength }(\mathrm{MPa})\end{array}$ \\
\hline \multicolumn{5}{|l|}{ Houses } \\
\hline H_01 & 1.24 & 273 & 7 & 0.13 \\
\hline H_02 & 1.00 & 203 & 7 & 0.19 \\
\hline H_03 & 0.75 & 97 & 14 & 0.19 \\
\hline H_04 & 0.66 & 51 & 28 & - \\
\hline H_05 & 2.15 & 448 & 6 & - \\
\hline H_09 & 0.70 & 87 & 10 & - \\
\hline H_10 & 1.98 & 334 & 7 & - \\
\hline H_11 & 1.08 & 143 & 9 & - \\
\hline \multicolumn{5}{|c|}{ Land dividing walls } \\
\hline W_01 & 0.94 & 138 & 8 & - \\
\hline W_02 & 0.83 & 117 & 9 & 0.13 \\
\hline W_04 & 0.99 & 200 & 6 & 0.12 \\
\hline W_05 & 1.72 & 340 & 8 & 0.40 \\
\hline W_06 & 1.25 & 209 & 8 & - \\
\hline W_07 & 0.80 & 94 & 10 & - \\
\hline W_09 & 1.05 & 114 & 14 & - \\
\hline W_10 & 0.98 & 127 & 11 & - \\
\hline
\end{tabular}



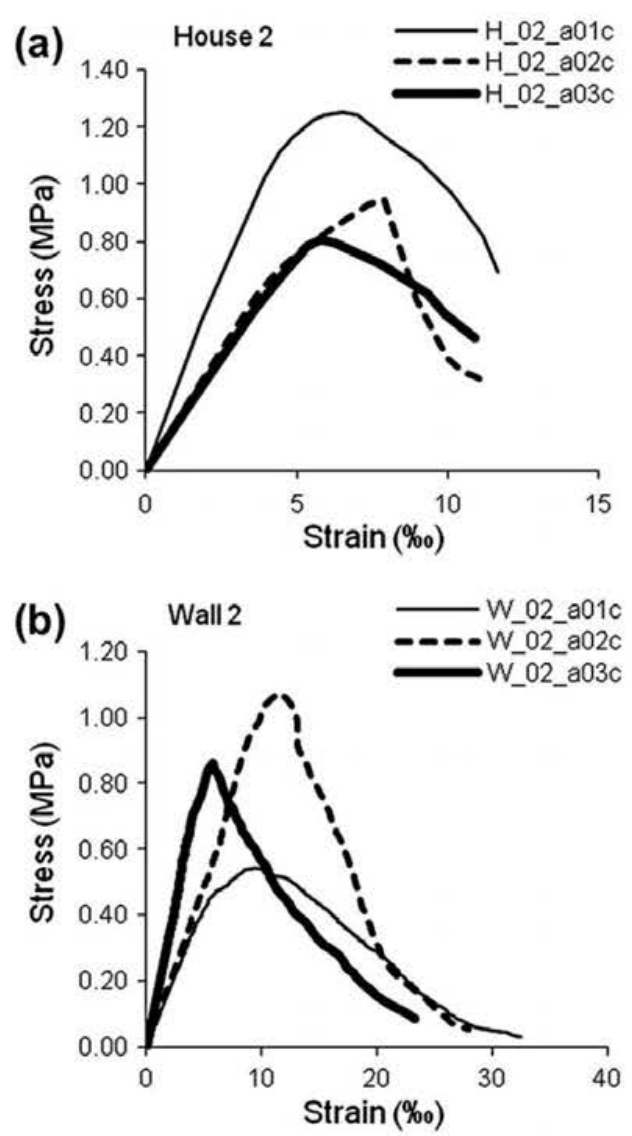

Fig. 4. Examples of stress vs. strain relations obtained in simple compression tests on adobe specimens.

To facilitate the identification of the specimens and the analysis, the adobe cylindrical specimens were classified and labelled according to their provenience and to the type of test conducted. The notation $\left\{\begin{array}{l}H \\ W\end{array}\right\}$ i_aj $\left\{\begin{array}{l}c \\ t\end{array}\right\}$ was adopted, distinguishing:
- Adobe specimens $(a)$ from houses $(H)$ and land dividing walls (W).

- Adobe specimens subjected to simple compression $(c)$ and splitting $(t)$ tests.

Index $i$ represents the number of the construction to which the specimen belongs, and index $j$ the number of the cylindrical specimen.

A total of 101 cylindrical specimens, 51 proceeding from houses and 50 from land dividing walls, were submitted to mechanical tests, using a universal mechanical compression testing machine (Shimadzu Autograph AG 25 TA). 83 specimens were submitted to compression, and 18 to splitting tests (Fig. 3).

In the performed tests a uniform load was applied without shock and increased continuously until failure, with the moving head of the testing machine travelling at a rate of $1-2 \mathrm{~mm} / \mathrm{min}$, respecting the rate limits recommended in the Australian handbook [20].

The testing rate limits indicated in 'CPC 6 Tension by splitting of concrete specimens' [22], for splitting tests, are for load-controlled devices, and the available testing machine is strain-controlled. In addition, concrete is a material with higher strength capacity and stiffness than adobe, and thus the use of these rate limits would be inadequate for the testing of adobe specimens. Therefore, in the conduction of splitting tests a rate of $1-2 \mathrm{~mm} / \mathrm{min}$ was also adopted.

\section{Results}

Compressive and tensile strengths of adobe bricks were obtained from simple compression and splitting tests, respectively (Table 1).

Compressive strength, $f_{c}$, is given by $f_{c}=F_{c} / A$, where $F_{c}$ is the failure load, and $A$ is the cross-sectional area that resists the load. The tensile strength, $f_{t}$, is given by $f_{t}=2 F_{t} /(\pi D H)$, where $F_{t}$ is the failure load, $D$ is the diameter of the specimen, and $H$ is the height of the specimen [22].

Modulus of elasticity $(E)$ and strain at peak strength $\left(\varepsilon_{\text {peak }}\right)$ were also estimated (Table 1) from the stress-strain behavior curves

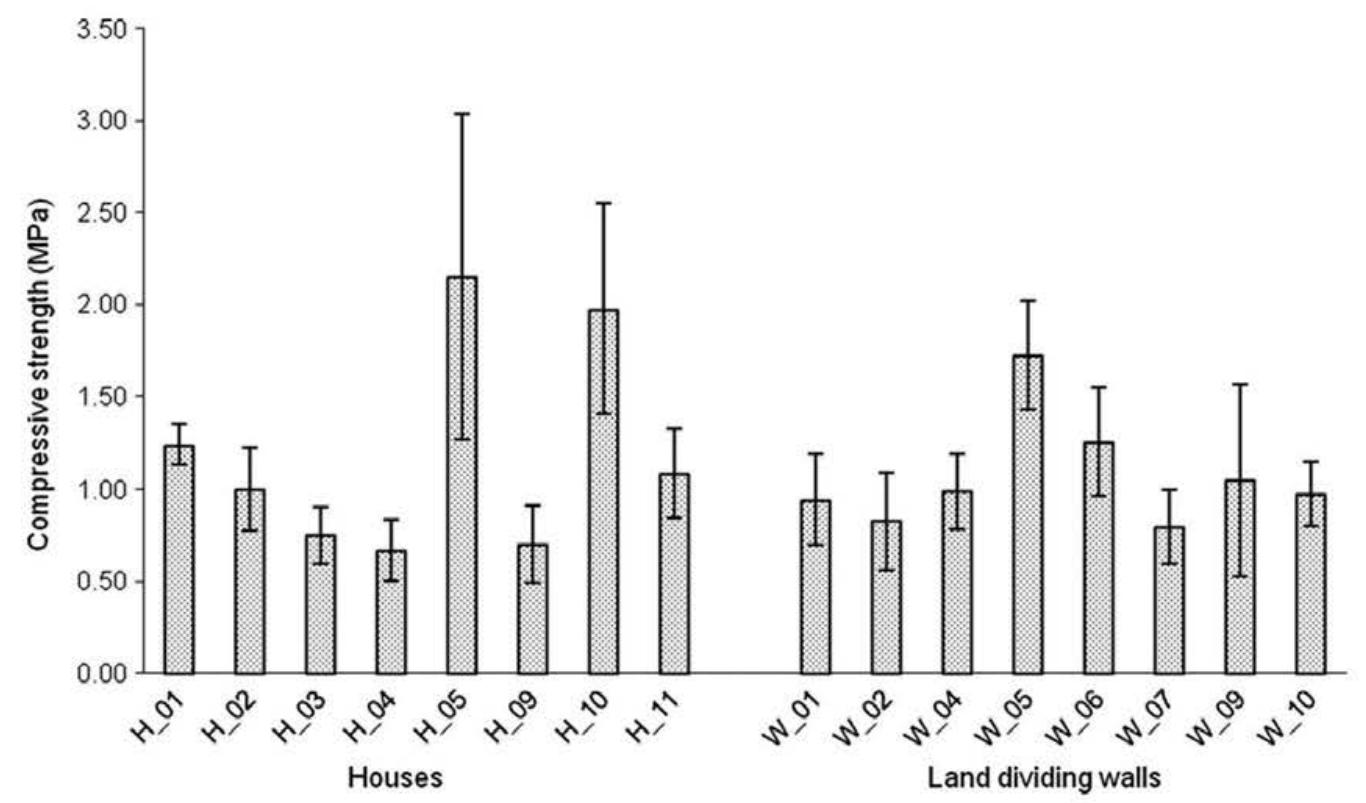

Fig. 5. Mean compressive strength of adobe specimens taken from houses $(H)$ and land dividing walls $(W)$, with indication of standard deviation. 


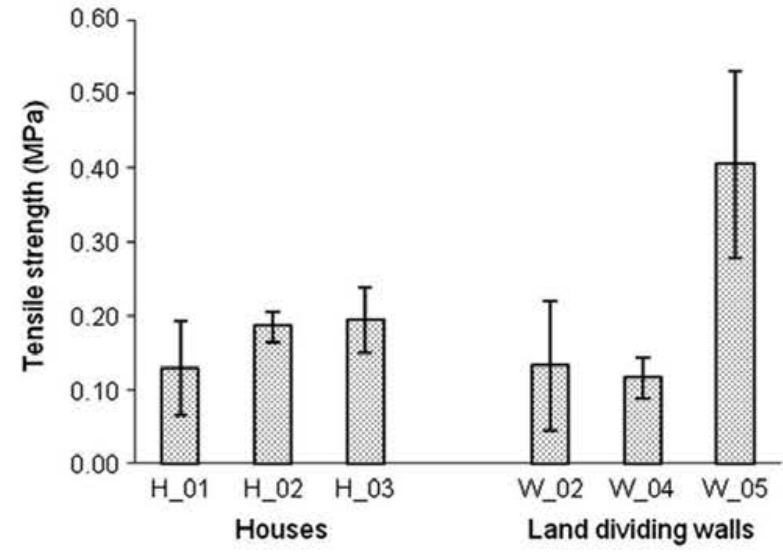

Fig. 6. Mean tensile strength of adobe specimens taken from houses $(H)$ and land dividing walls $(W)$, with indication of standard deviation.

obtained in simple compression tests (Fig. 4). It is important to note that the deformations measured correspond to the relative displacements of the testing machine platens.

\section{Analysis and discussion of results}

\subsection{Compressive and tensile strengths}

The mean compressive strength, calculated per construction under analysis, ranges between $0.66 \mathrm{MPa}\left(\mathrm{H}_{-} 04\right)$ and $2.15 \mathrm{MPa}$ (H_05) (Fig. 5). The global mean compressive strength for specimens taken from houses is $1.32 \mathrm{MPa}$, and for specimens from land dividing walls is approximately $78 \%$ of that value ( $1.03 \mathrm{MPa})$. The results obtained for some of the analyzed constructions present high variability, which is expressed by the standard deviations presented in Fig. 5 . The variability between the mean results obtained for different constructions is also significant, and is larger (about
Table 4

Values of strength for adobes from constructions in different locations.

\begin{tabular}{lll}
\hline Location & Compressive strength (MPa) & Tensile strength (MPa) \\
\hline Aveiro - Portugal & 1.17 & 0.19 \\
Mexico [24] & 1.18 & 0.27 \\
Mexico [25] & $0.51-1.57$ & $0.20-0.43$ \\
Colombia [26] & 3.04 & 0.41 \\
Morocco [27] & $2.83^{\mathrm{a}}$ & $0.18-0.35$ \\
Italy [28] & $0.29-1.56$ & $0.17-0.40$ \\
\hline
\end{tabular}

${ }^{a}$ Results obtained from in situ sclerometer tests.

1.9 times) for houses, which present the lowest and highest mean compressive strength values (Fig. 5).

The mean tensile strength, calculated per construction under analysis, ranges between $0.12 \mathrm{MPa}\left(W \_04\right)$ and $0.40 \mathrm{MPa}\left(W \_05\right)$ (Fig. 6). The global mean tensile strength for specimens taken from land dividing walls is $0.22 \mathrm{MPa}$, and for specimens from houses is approximately $78 \%$ of that value $(0.17 \mathrm{MPa})$. The results obtained for some of the constructions under analysis present high variability, expressed by the standard deviations presented in Fig. 6 . The variability between the mean results obtained for different constructions is also considerable.

Tables 2 and 3 present the limits indicated by different standards for compressive and tensile strengths, and the number of constructions analyzed that respect these limits. The strength values obtained for the tested adobe bricks are, in general, inferior to the minimum established limits. This comparative analysis is not rigorous, given that the strict indications of each standard for the conduction of tests were not followed, and that there are differences between splitting tensile strength and flexural tensile strength (compared in Table 3) that result from the different characteristics of the respective testing procedures and specimens. This analysis is only intended to provide a general indication of the quality of the studied adobes in terms of mechanical strength, compared to what is required for new constructions.

Values of strength obtained by other authors [24-28] for adobes from constructions in different countries are presented in Table 4 ,

Table 2

Evaluation of obtained compressive strength values by comparison with normative limits.

\begin{tabular}{|c|c|c|c|}
\hline \multirow[t]{2}{*}{ Standard } & \multirow[t]{2}{*}{ Compressive strength limit } & \multicolumn{2}{|c|}{$\begin{array}{l}\text { No. of constructions analyzed } \\
\text { that respect the limit }\end{array}$} \\
\hline & & $\begin{array}{l}\text { Houses (out of } \\
\text { a total of } 8 \text { ) }\end{array}$ & $\begin{array}{l}\text { Walls (out of } \\
\text { a total of } 8 \text { ) }\end{array}$ \\
\hline $\begin{array}{l}\text { NZS 4298:1998 } \\
\quad(\text { New Zealand) [17] }\end{array}$ & - Least of the individual results in the set $>0.7 \times 1.30 \mathrm{MPa}^{\mathrm{a}}$ & 3 & 1 \\
\hline NTE E.080 (Peru) [15] & - Compressive strength value that is exceeded in $80 \%$ of the tested specimens $s^{\mathrm{b}} \geqslant 0.7 \times 1.18 \mathrm{MPa}^{\mathrm{b}}$ & 3 & 3 \\
\hline $\begin{array}{l}\text { 14.7.4 NMAC } \\
\text { (New Mexico) [19] }\end{array}$ & $\begin{array}{l}\text { - Mean compressive strength } \geqslant 2.07 \mathrm{MPa}^{\mathrm{c}} \\
\text { - One sample out of the total may have a compressive strength of not less than } 1.72 \mathrm{MPa}^{\mathrm{c}}\end{array}$ & 0 & 0 \\
\hline
\end{tabular}

a This standard indicates cubic specimens for the compressive test. In the calculation of the unconfined compressive strength limit, an aspect ratio factor of ' 0.7 ', which is indicated in the standard for cubic specimens, was introduced. This strength limit is for 'standard grade earth construction', as defined in the standard.

b The compressive strength value that is exceeded in $80 \%$ of the tested specimens was calculated considering a normal distribution of results.

c This standard indicates that the compressive test shall be conducted on adobe blocks, in the flat position, but it does not indicate the dimensions of the blocks to be tested, nor recommends the use of an aspect ratio factor to take the confinement effect into account; therefore, these limit values are here considered without any correction and are thus significantly larger than the other limit values presented.

Table 3

Evaluation of obtained tensile strength values by comparison with normative limits.

\begin{tabular}{|c|c|c|c|}
\hline \multirow[t]{2}{*}{ Standard } & \multirow[t]{2}{*}{ Tensile strength limit ${ }^{\mathrm{a}}$} & \multicolumn{2}{|c|}{ No. of constructions analyzed that respect the limit } \\
\hline & & Houses (out of a total of 3 ) & Walls (out of a total of 3 ) \\
\hline NZS 4298:1998 (New Zealand) [17] & - Least of the individual results in the set $>0.25 \mathrm{MPa}^{\mathrm{b}}$ & 0 & 1 \\
\hline NTE E.080 (Peru) [15] & - No indication & - & - \\
\hline 14.7.4 NMAC (New Mexico) [19] & - Mean tensile strength $\geqslant 0.34 \mathrm{MPa}$ & 0 & 1 \\
\hline
\end{tabular}

\footnotetext{
${ }^{a}$ Flexural tensile strength.

b This strength limit is for 'standard grade earth construction', as defined in NZS 4298:1998 standard.
} 


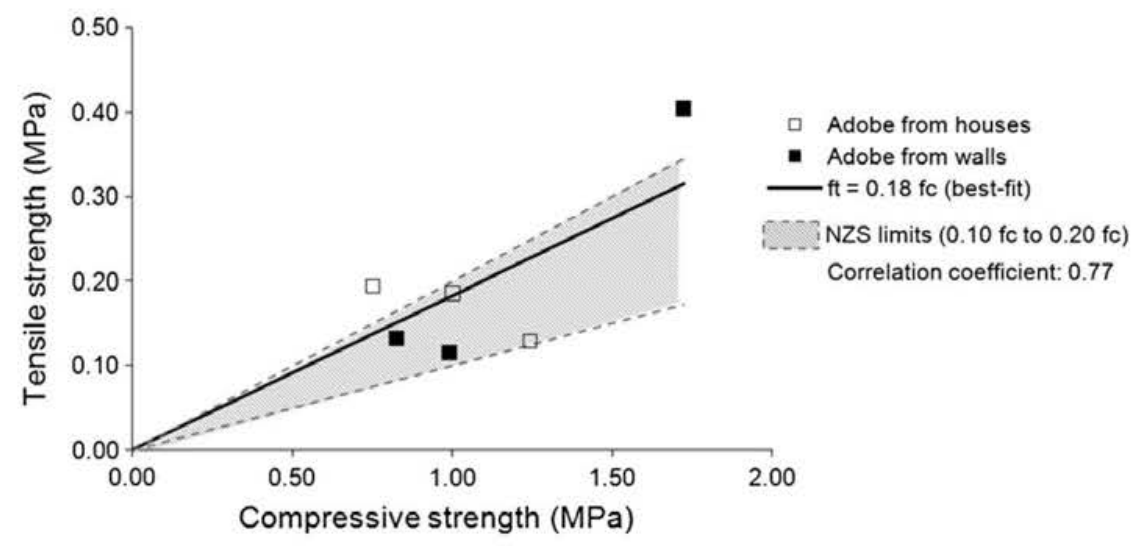

Fig. 7. Correlation between tensile and compressive strengths, with indication of the limits presented in NZS 4298:1998 [17].

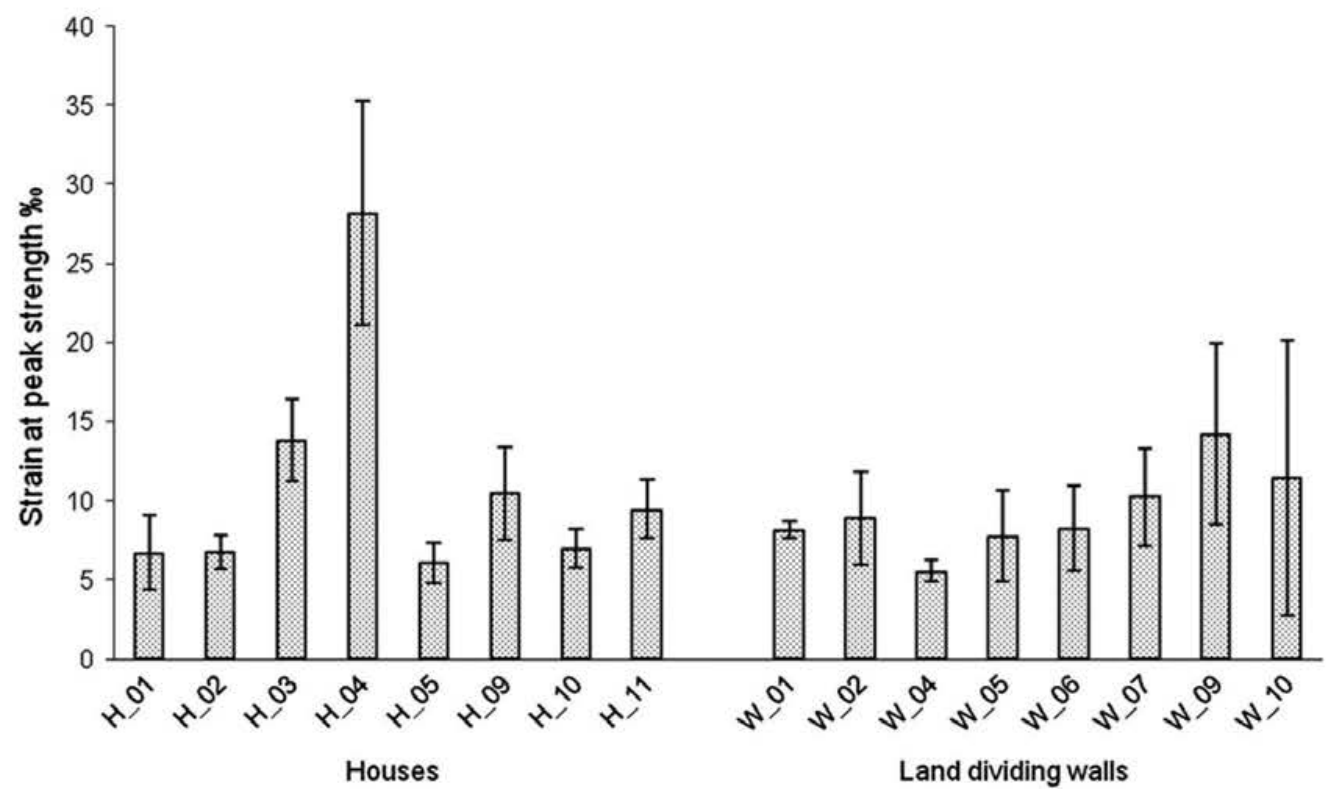

Fig. 8. Mean strain at peak strength of adobe specimens taken from houses $(H)$ and land dividing walls $(W)$, with indication of standard deviation.

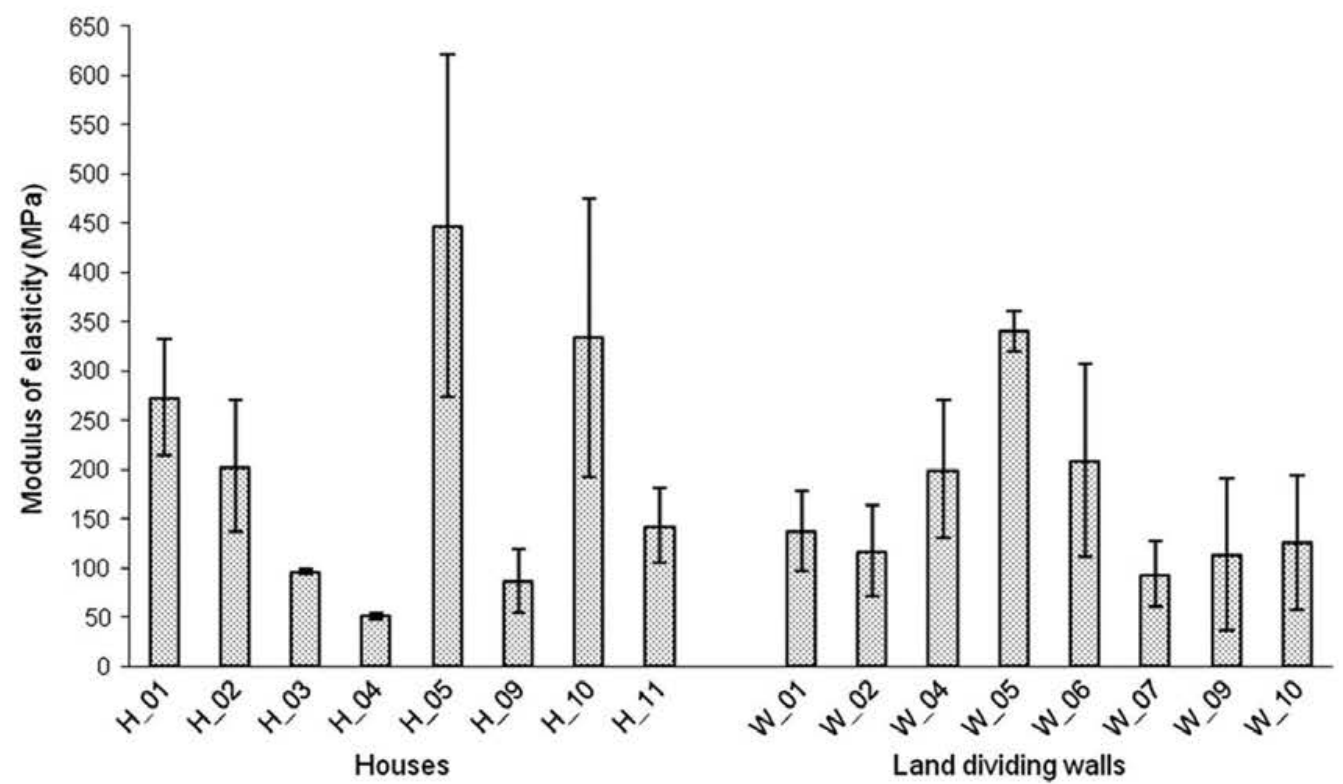

Fig. 9. Mean modulus of elasticity of adobe specimens taken from houses $(H)$ and land dividing walls $(W)$, with indication of standard deviation. 
together with the mean results obtained in the present study. In the majority of studies, simple compression tests were conducted on adobe bricks (or half bricks), and authors do not refer if a correction associated to the confinement effect was taken into consideration. The tensile strength values presented in these studies result from three point bending tests, while the values obtained in the present study result from splitting tests. Therefore, this comparative analysis is not rigorous, and aims only to provide a general indication of the quality of the studied adobes by comparison with adobes from constructions in other countries. From the comparison, it is verified that the obtained values are within the range of
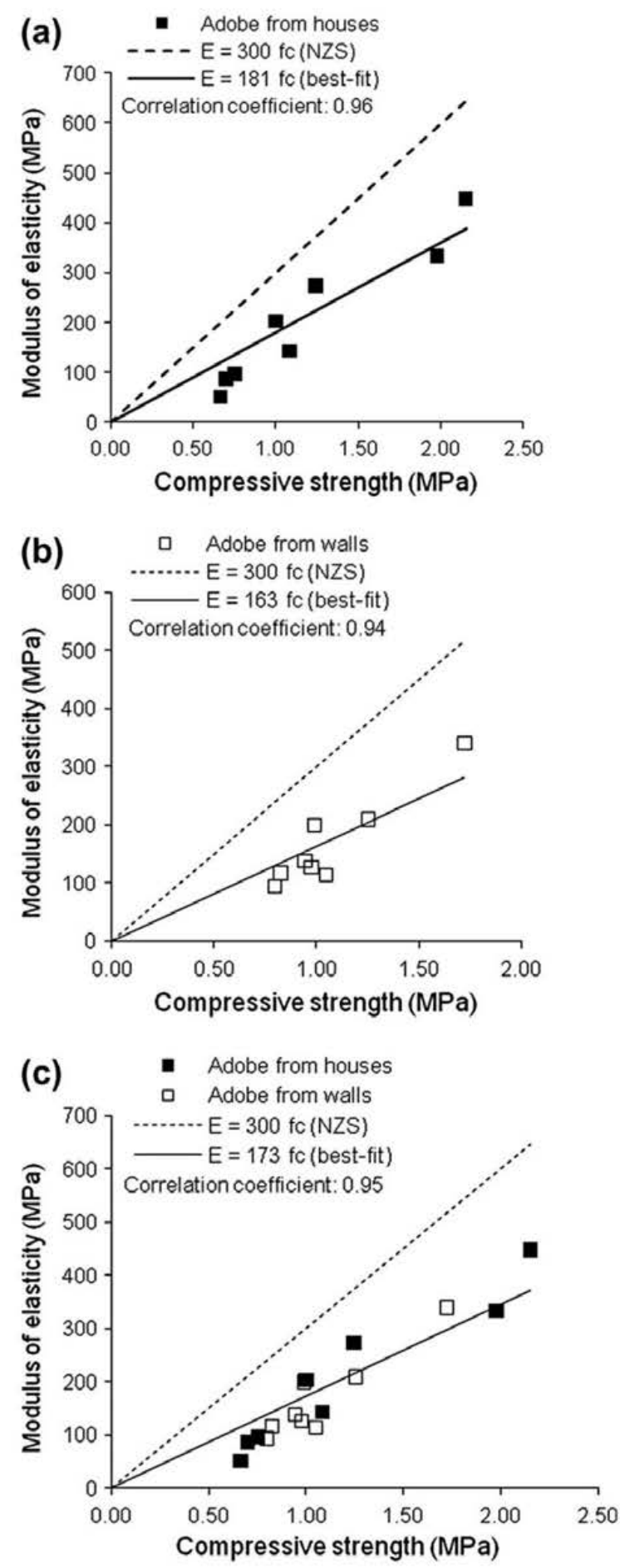

Fig. 10. Correlations between modulus of elasticity and compressive strength, for houses, land dividing walls, and all constructions. results obtained by other authors. Higher compressive strength values, in some of the studies, may be justified, in part, by the confinement effect in the testing of adobe blocks.

The correlation between the tensile and compressive strengths of the tested specimens was studied. For each construction analyzed, the mean tensile strength was plotted against the respective mean compressive strength, and the best-fit linear correlation was determined (Fig. 7). According to this best-fit correlation, tensile strength corresponds to approximately $18 \%$ of compressive strength.

'NZS 4298:1998 Materials and workmanship for earth buildings' [17] indicates that flexural tensile strength generally lies between $10 \%$ and $20 \%$ of compressive strength, and that the majority of results lie below $30 \%$. Thus, the correlation obtained for the studied adobe specimens from splitting tensile tests is within the limits suggested in this standard for flexural tensile strength (Fig. 7).

According to the Australian handbook [20], the design characteristic compressive strength of adobe walls can be directly estimated from the experimental characteristic compressive strength of adobe bricks affected by a reduction factor of 0.4 . The design characteristic compressive strength of adobe walls was estimated with this procedure for each construction analyzed. It varies between $0.08 \mathrm{MPa}$ (W_09) and $0.50 \mathrm{MPa}$ (W_05), and presents a global mean value of $0.27 \mathrm{MPa}$ for houses and of $0.25 \mathrm{MPa}$ for land dividing walls.

\subsection{Strain at peak strength}

The mean strain at peak strength, calculated per construction under analysis, ranges between $5.5 \%\left(W_{-} 04\right)$ and $28.2 \%$ ( $\left.H \_04\right)$ (Fig. 8). The global mean strain at peak strength for specimens taken from land dividing walls is of $10.3 \%$, and for specimens from houses is approximately $95 \%$ of that value $(9.8 \%)$.

The results obtained for some of the analyzed constructions present high variability, which is reflected in the standard deviations presented in Fig. 8. The variability between the mean results obtained for different constructions is also significant, and is larger (about 2.8 times) for houses, with house $H \_04$ standing out with a mean strain value much larger than the obtained for other constructions (Fig. 8).

\subsection{Modulus of elasticity}

The mean modulus of elasticity, calculated per construction under analysis, ranges between $51 \mathrm{MPa}\left(H \_04\right)$ and $448 \mathrm{MPa}\left(H \_05\right)$

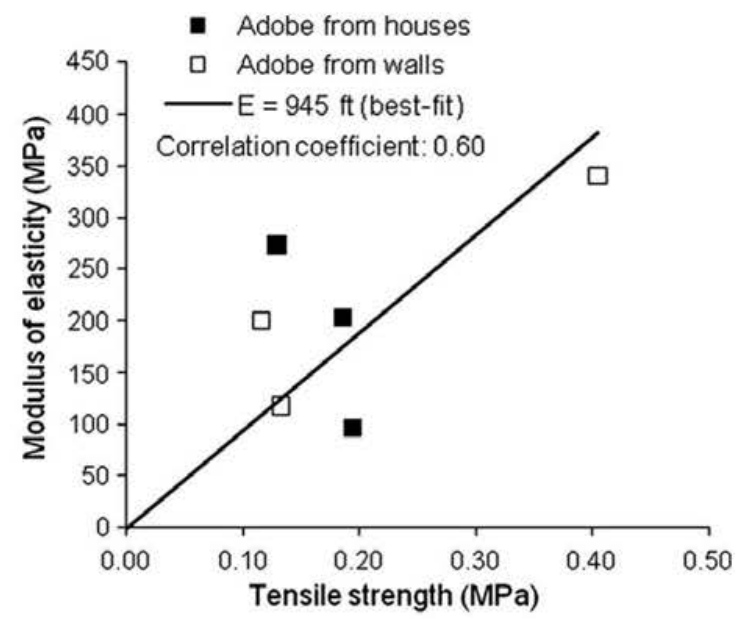

Fig. 11. Correlation between modulus of elasticity and tensile strength 
Table 5

Mean results obtained in the performed tests.

\begin{tabular}{|c|c|c|c|c|}
\hline & $\begin{array}{l}\text { Mean compressive } \\
\text { strength (MPa) }\end{array}$ & $\begin{array}{l}\text { Mean modulus of } \\
\text { elasticity (MPa) }\end{array}$ & $\begin{array}{l}\text { Mean strain at } \\
\text { peak strength }(\% o)\end{array}$ & $\begin{array}{l}\text { Mean tensile } \\
\text { strength (MPa) }\end{array}$ \\
\hline Houses & 1.32 & 225 & 9.8 & 0.17 \\
\hline Land dividing walls & 1.03 & 147 & 10.3 & 0.22 \\
\hline All constructions & 1.17 & 187 & 10.1 & 0.19 \\
\hline
\end{tabular}

(Fig. 9). The global mean modulus of elasticity for specimens taken from houses is of $225 \mathrm{MPa}$, and for specimens from land dividing walls is approximately $65 \%$ of that value $(147 \mathrm{MPa})$.

The results obtained for many of the analyzed constructions present high variability, expressed by the standard deviations presented in Fig. 9. The variability between the mean results obtained for different constructions is also important, and is larger (about 1.7 times) for houses, which present the lowest and highest mean modulus of elasticity values (Fig. 9).

The correlation between the modulus of elasticity and compressive strength of the tested specimens was studied. For each construction analyzed, the mean modulus of elasticity was plotted against the respective mean compressive strength (Fig. 10). A linear correlation is evident and, to represent it, 3 best-fit lines were determined (Fig. 10) - considering the mechanical results from houses, from land dividing walls, and all results together. The following correlations were obtained: $E=181 f_{c}$, for houses; $E=163 f_{c}$ for land dividing walls; and $E=173 f_{c}$, for all constructions. 'NZS 4297:1998 Engineering design of earth buildings' [16] proposes a correlation of $E=300 f_{c}$ for adobe masonry walls, which is also presented in Fig. 10.

The correlation between the modulus of elasticity and tensile strength of the tested specimens was also studied, considering all the results (from houses and land dividing walls) as there are fewer results for tensile strength. For each construction analyzed, the mean modulus of elasticity was plotted against the respective mean tensile strength, and the following best-fit linear correlation was determined: $E=945 f_{t}$ (Fig. 11).

\section{Global appreciation of results and conclusions}

A summary of the mean results obtained in the performed tests is presented in Table 5. Houses present mean compressive strength and modulus of elasticity values superior to the ones presented by land dividing walls, and the opposite is verified for tensile strength values.

The results obtained for some of the analyzed houses and land dividing walls present high variability. The variability between the mean results obtained for different constructions is also significant and is in general considerably larger for houses. High variability of results was expected since, traditionally, the materials used in the production of adobes presented important heterogeneities and there were variances in production and curing procedures, even within the same construction process.

The results obtained are essential for the characterization of adobes used in traditional masonries of Aveiro district, and constitute important reference values to be considered in the rehabilitation of existing constructions and in the calibration of numerical models. It should be noted, however, that tests performed on adobe specimens can only be used as indicators of the quality of adobe, and not of masonry $[15,29]$. Other studies have been developed by this research team to contribute to the characterization of the mechanical behavior of the adobe masonry system, by the experimental testing of masonry specimens $[12,30]$.

The lack of European and, in particular, Portuguese normalization dedicated to earth construction became evident in the conduc- tion of this study. The inexistence of recommendations directed to earth construction in the Eurocodes was also verified. Furthermore, the existing normalization is not complete and requires improvements. It is directed to the construction of new buildings and should also consider the rehabilitation of existing constructions, since there is a vast patrimony of earth construction in need of adequate repair and strengthening interventions. The procedures adopted in this study may serve as reference in the development of recommendations regarding the conduction of tests for the mechanical characterization of adobes from existing constructions.

\section{Role of the funding source}

This paper reports research work that is part of doctoral studies funded by a scholarship provided by "FCT - Fundação para a Ciência e Tecnologia", Portugal.

\section{Acknowledgments}

The authors express their acknowledgments to: CIVILRIA S.A. for the transport of adobe bricks to the laboratory; all persons who kindly opened their homes for samples collecting; Câmara Municipal de Aveiro for all the collaboration in the studies that have been conducted regarding adobe construction.

\section{References}

Houben H, Guillaud H. Earth construction: a comprehensive guide. London: ITDG Publishing: 1994.

Oliveira EV, Galhano F. Traditional Portuguese architecture. Lisbon: Publicações D. Quixote; 1992 [in Portuguese].

Jean-Nicolas L, Adília A, António JC, editors. Earth architectures seminar. In: Proceedings of the seminário arquitecturas de terra, 1990 July, Coimbra Portugal. Coimbra: Comissão de Coordenação da Região Centro; 1992 [in Portuguese].

Castro A. The traditional constructive system in a period of transition of architecture languages. The modern movement and the adobe. Dissertation, Faculty of Engineering of the University of Porto, Porto; 2009 [in Portuguese]. Silva S, Varum H, Bastos D, Silveira D. Earthen architecture - investigation and characterization of adobe buildings in Murtosa municipality. In: Maria F Mariana C, Filipe J, editors. Terra em seminário 2010. Lisbon: Argumentum; 2010. p. 236-9 [in Portuguese].

Silveira D, Varum H, Costa A, Lima E. Survey and characterization of the adobe built park in Aveiro city. In: Proceedings of $6^{\circ}$ Seminário de Arquitectura de Terra em Portugal and $9^{\circ}$ Seminário Ibero-Americano de Construção e Arquitectura com Terra [CD-ROM], Coimbra, Portugal; February 20-23, 2010 [in Portuguese].

North G, Kanuka-Fuchs R. Waitakere City Council's sustainable home guidelines - earth building [Internet]. Waitaker: Waitakere City Council; 2008. <http://www.waitakere.govt.nz/abtcit/ec/bldsus/pdf/materials/earth building.pdf $>$ [accessed 01.05.11].

Webster F, Tolles E. Earthquake damage to historic and older adobe buildings during the 1994 Northridge, California Earthquake. In: Proceedings of the 12th world conference on earthquake engineering [CD-ROM], Auckland, New Zealand: January 30-February 4, 2000.

Ocola L, Huaco P. Seismic response of adobe buildings in Peruvian territory: 1974-2001 earthquakes. In: Proceedings of SismoAdobe2005 [CD-ROM], Lima, Peru; May 16-19, 2005 [in Spanish].

Hernandez RS, Barrios MS, Pozas JMM. Characterization of ancient construction materials (mud walls and adobe) in the Churches of Cisneros, Villada and Boada de Campos (Palencia). Materiales de Construcción 2000;50(257):33-45.

Neto $C$. Strategy for the characterization of adobe heritage constructions in Aveiro, Dissertation, University of Aveiro, Aveiro; 2008 [in Portuguese]. 
Varum H, Figueiredo A, Silveira D, Martins T, Costa A. Outputs from the research developed at the University of Aveiro regarding the mechanical characterization of existing adobe constructions in Portugal. Informes de la Construcción 2011:63(523):127-42.

Oliveira C, Varum H, Figueiredo A, Silveira D, Costa A. Experimental tests for seismic assessment and strengthening of adobe structures. In: Proceedings of the 14th European conference on earthquake engineering [CD-ROM]. Ohrid, Republic of Macedonia: August 30-September 3, 2010. Abstract in: Book of Abstracts. Ohrid: MAEE, Macedonian Association for Earthquake Engineering; 2010.

Morel JC, Pkla A, Walker P. Compressive strength testing of compressed earth blocks. Constr Build Mater 2007;21(2):303-9.

Reglamento nacional de construcciones. Norma técnica de edificación NTE E.080 Adobe. Lima: SENCICO; 2000.

NZS 4297:1998 Engineering design of earth buildings. Wellington: Standards New Zealand; 1998.

NZS 4298:1998 Materials and workmanship for earth buildings. Wellington: Standards New Zealand; 1998.

NZS 4299:1998 Earth buildings not requiring specific design. Wellington: Standards New Zealand; 1998.

14.7.4: 2009 New Mexico earthen building materials code - New Mexico administrative code. New Mexico, USA; 2009.

Walker P. The Australian earth building handbook, HB 195-2002. Sydney: Standards Australia; 2002.

Lamond JF, Pielert JH. Significance of tests and properties of concrete and concrete-making materials. New York: ASTM International; 2006.

RILEM. CPC 6 tension by splitting of concrete specimens, 1975. In: RILEM technical recommendations for the testing and use of construction materials. London: E\&FN Spon; 1994. p. 21-2.
Illston JM, Domone PLJ. Construction materials: their nature and behaviour. In: Illston JM. Domone PLJ, editors. United Kingdom: T\&F Books: 2010.

Gavrilovic P. Sendova V. Ginell WS, Tolles L. Behaviour of adobe structures during shaking table tests and earthquakes. In: Proceedings of the 11th European conference on earthquake engineering [CD-ROM], Rotterdam, Netherlands; September 6-11, 1998.

Meli R. Experiences in Mexico on the reduction of seismic vulnerability of adobe constructions. In: Proceedings of SismoAdobe2005 [CD-ROM], Lima, Peru; May 16-19, 2005 [in Spanish].

Rivera JC, Muñoz EE. Structural characterization of materials of earth structural systems: adobe [in Spanish], Revista Internacional de Desastres Naturales. Accidentes e Infraestructura Civil 2005;5(2):135-48.

Baglioni E, Fratini F, Rovero L. The materials utilised in the earthen buildings sited in the Drâa Valley (Morocco): mineralogical and mechanical characteristics. In: Proceedings of $6^{\circ}$ Seminário de Arquitectura de Terra em Portugal and $9^{\circ}$ Seminário Ibero-Americano de Construção e Arquitectura com Terra [CD-ROM], Coimbra, Portugal; February 20-23, 2010.

Liberatore D, Spera G, Mucciarelli M, Gallipoli MR, Santarsiero D, Tancredi C, et al. Typological and experimental investigation on the adobe buildings of Aliano (Basilicata, Italy). In: Lourenço PB, Roca P, Modena C, Agrawal S, editors. Proceedings of the 5th international conference on structural analysis of historical constructions. India: Macmillan India: November 6-8, 2006. p. 851-8. Ottazzi G. Normalization of tests on adobe masonry. In: Arquitectura de tierra: Encuentros Internacionales Centro de Investigación Navapalos. Madrid: Ministerio de Fomento; 1998. p. 83-94. p. 83-94 [in Spanish]. Varum H, Costa A, Pereira H, Almeida J. Silveira D. Mechanical characterization of adobe masonry walls. In: Proceedings of the 13th conference of sociedade portuguesa de materiais and IV international materials symposium - a materials science forum [CD-ROM], Porto, Portugal; April 1-4, 2007. 